\title{
POTENSI DAN PENINGKATAN KUALITAS NUTRISI BUAH TOMAT (Lycopersicon esculentum) AFKIR SEBAGAI PAKAN TERNAK UNGGAS
}

\author{
U. F. HANDAYANI', M. E. MAHATA2, Y. RIZAL2 ${ }^{2}$ I. SULIANSYAH ${ }^{3}$, DAN WIZNA2 \\ ${ }^{1}$ Mahasiswa Pascasarjana Universitas Andalas, Kampus Limau Manis, Padang, Indonesia, 25163 \\ 2 Dosen Fakultas Peternakan, Universitas Andalas, Kampus Limau Manis, Padang, Indonesia, 25163 \\ ${ }^{3}$ Dosen Fakultas Pertanian, Universitas Andalas, Kampus Limau Manis, Padang, Indonesia, 25163 \\ E-Mail: ulvifitrihandayani@yahoo.com
}

\begin{abstract}
One of the important things in determining the quality of livestock products is feed ingredients. The quality of Poultry products will be influenced by the nutrient intake provided. Tomato reject is one of the special ingredients of a feed because it contains high lycopene. Lycopene is well known as an antioxidant, also it can lower cholesterol content. However, lycopene still in the matrix of tomato tissue and trans-form lycopene what difficult to digest and absorb in the body. So, in this paper presents the extent to which the development of research utilization of tomatoes high lycopene as poultry feed. As well as opening more widely how to increase the value of lycopene tomatoes in poultry products.
\end{abstract}

Keywords: feed ingredients, lycopene, tomatoes, and poultry.

\section{PENDAHULUAN}

Bahan pakan merupakan hal yang penting dalam dunia perunggasan. Pakan yang berkualitas akan menghasilkan produk yang berkualitas. Beberapa dekade ini pencarian bahan pakan yang juga memiliki kandungan lain yang dapat meningkatkan kualitas produk ternak sangat diminati untuk dijadikan topik penelitian. Salah satunya adalah bahan pakan yang juga mengandung zat-zat fitokimia sebagai pengganti antioksidan, antibiotik dan penurun kolesterol. Salah satu zat fitokimia yang dihasilkan oleh buah buahan yang berwarna merah dan dapat berfungsi sebagai antioksidan, anti kanker dan penurun kolesterol adalah likopen (Rao, et al., 2006; Chauhan,et al., 2011;Palozza, et al.,2012).

Tomat (Licopersicon esculentum) adalah salah satu produk pertanian yang hasilnya melimpah di Indonesia. Selain melimpah produksi tomat di Indonesia juga sering kali melebihi kebutuhan pasarnya. Pada Out lock komoditi tomat, 2014 yang diterbitkan Kementrian Pertanian menunjukan produksi tomat selalu mengalami peningkatan sejak tahun 1990.
Direktur Jenderal Perdagangan Dalam Negeri Kementerian Perdagangan Srie Agustina menyatakan hampir setiap tahun Indonesia surplus produksi tomat kurang lebih 396 ribu-400 ribu ton (Jannah, 2015; Novita, 2015).

Pengamatan di berbagai media dan juga di lapangan didapatkan musim panen tertentu produksi tomat melimpah (over production) dan harga tomat sangat rendah. Kondisi ini membuat petani merugi dan akibatnya banyak petani yang tidak memanen tomatnya. Tomat dibiarkan dipohon karena biaya pemanenan lebih mahal daripada harga jualnya. Sehingga banyak yang tidak termanfaatkan, padahal tomat memiliki kandungan likopen yang tinggi.

Analisis proksimat kandungan gizi limbah tomat adalah : 10,73\% protein; 2,81\% lemak kasar, 0,19\% Ca; 0,28\% P; 25,19\% serat kasar; $1013.14 \mathrm{kkal} / \mathrm{kg}$ energi metabolisme, dan 557,37 ppm likopen (Mahata et al., 2016). Clinton (1998) menyebutkan $60-64 \%$ dari total karoten dalam tomat merupakan likopen; Shi, et al. (1999) melaporkan 83\% dari total karoten yang terkandung. Oleh karena itu, tomat 
dapat dimanfaatkan sebagai pakan alternatif ternak unggas yang memiliki likopen yang tinggi.

Likopen merupakan pigmen alami yang dapat disintesis oleh tanaman dan mikroorganisme seperti fungi, bakteri, dan alga (Shi and Maguer, 2000). Likopen pada tanaman banyak ditemukan pada buah-buahan dan sayuran berwarna merah seperti tomat, semangka, anggur, jambu biji dan aprikot, sedangkan hewan dan manusia tidak dapat mensintesis likopen tetapi sangat dibutuhkan tubuh sehingga perlu diberikan dalam bahan pakan yang dikonsumsinya (Tapiero et al., 2004; Omoni and Aluko 2005; Olson, et al., 2008).

Secara biologis likopen memiliki berbagai fungsi dalam tubuh diantaranya, likopen berfungsi sebagai zat antioksidan yang tinggi untuk mencegah reaksi oksidatif di dalam sel (Young and Lowe, 2001; Stahl and Sies, 2003; Tapiero et al., 2004). Likopen juga dikenal mempunyai kemampuan menurunkan kolesterol (Fuhramn et al., 1997; Rao, et al.,2006; Palozza, et al., 2012). Artikel ini akan berfokus pada potensi buah tomat afkir sebagai bahan pakan dan meningkatkan kualitas likopen buah tomat afkir. Sehingga keuntungan dari kandungan likopen yang melimpah dalam buah tomat dapat dimaksimalkan manfaatnya.

\section{KETERSEDIAAN LIMBAH TOMAT UTUH SEBAGAI PAKAN DI INDONESIA.}

Tomat (Licopersicon esculentum) merupakan salah satu produk pertanian yang hasilnya melimpah di Indonesia. Ahli-ahli botani mengklasifikasikan tanaman tomat secara sistemik (Steenis,1997; Tugiyono, 2005).

Divisi : Spermatophyta

Subdivisi : Angiospermae

Kelas : Dicotyledonae (berkeping dua)

Ordo : Tubiflorae

Famili : Solanaceae (berbunga seperti terompet)
Genus : Solanum (Lycopersicum)

Species : Lycopersicum esculentum Mill

Berdasarkan data Badan Pusat Statistik (BPS) produktifitas tomat dari tahun 2011 sampai 2015 selalu di atas 15 ton per hektarnya dengan produksi di atas 900 ribu ton per tahun. Produksi tomat di Indonesia sangat melimpah dan meningkat dari tahun ke tahun. Dari tahun 1990 hingga 2014 menunjukan grafik produksi yang semakin meningkat yaitu dari 300 ribu ton setahun hingga 1 juta ton setahun. Melimpahnya produksi tomat di Indonesia juga sering kali melebihi kebutuhan pasarnya.

Indonesia merupakan negara yang memiliki produksi tomat terbanyak dibandingkan negara-negara ASEAN. Indonesia yang tersebar dari sabang sampai Merauke ini memiliki daerah yang tinggi produksi tomat. Berbagai daerah sentra produksi tomat di Indonesia seperti di Jawa barat, Jawa Timur, Jawa Tengah, Sumatera Utara dan Sumatera Barat. Pada kondisi tertentu seperti saat over produksi, harga tomat rendah dan tomat saat pemanenan ke 7-8 banyak ditemukan tomat yang tidak dipanen atau menjadi limbah karena tidak terjual seperti Gambar 1. Maka sangat memungkinkan menggunakan buah tomat kondisi tersebut untuk dijadikan pakan yang memiliki kandungan nutrisi yang sangat baik.

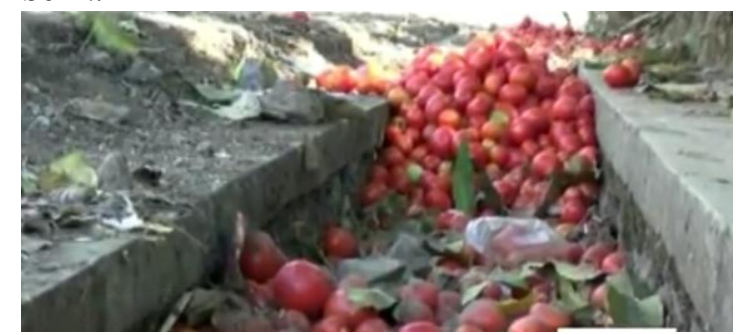

Gambar 1. Tomat dibuang di selokan di sentra produksi tomat Garut Jawa Barat (sumber: Agustinus, M, 2015). 


\section{KANDUNGAN NUTRISI LIMBAH TOMAT.}

Tomat (Lycopersicum esculentum) adalah tumbuhan dari keluarga Solanaceae, tumbuhan asli Amerika Tengah dan Selatan dari Meksiko sampai Peru. Beberapa jenis tomat yang banyak di tanam di Indonesia diantaranya tomat cerry, apel, kriting dan tomat recento.
Salah satu syarat suatu bahan dapat dijadikan sebagai bahan pakan adalah memiliki kandungan nutrisi yang dibutuhkan oleh ternak. Telah banyak penelitian penggunaan limbah tomat sebagai bahan pakan di berbagai negara. Kandungan nutrisi berbagai limbah tomat dapat di lihat pada tabel berikut.

Tabel 1. Kandungan nutrisi berbagai jenis limbah tomat.

\begin{tabular}{|c|c|c|c|c|c|c|c|c|}
\hline \multirow{2}{*}{$\begin{array}{l}\text { Jenis limbah } \\
\text { tomat }\end{array}$} & \multirow[b]{2}{*}{ PK } & \multirow[b]{2}{*}{ SK } & \multicolumn{4}{|c|}{ Kandungan nutrisi } & \multirow[b]{2}{*}{ Likopen } & \multirow[t]{2}{*}{ Sumber } \\
\hline & & & LK & $\mathrm{ME}$ & $\mathrm{Ca}$ & $\mathrm{P}$ & & \\
\hline Tomat utuh & $10,73 \%$ & $25,19 \%$ & $2,18 \%$ & $\begin{array}{l}1014,14 \\
\mathrm{kkal} / \mathrm{kg}\end{array}$ & $0,19 \%$ & $0,28 \%$ & $\begin{array}{l}557,37 \\
\text { ppm }\end{array}$ & Mahata, et al., 2016 \\
\hline Tomat utuh & $16,73 \%$ & $30,94 \%$ & $1,53 \%$ & $\begin{array}{l}2416 \mathrm{kkal} \\
/ \mathrm{kg}\end{array}$ & $0,98 \%$ & $1,2 \%$ & - & $\begin{array}{l}\text { Timbuleng et al, } \\
2015\end{array}$ \\
\hline Tomato pulp & $20,7 \%$ & $35,00 \%$ & $7,30 \%$ & $\begin{array}{l}1760 \\
\mathrm{kkal} / \mathrm{kg}\end{array}$ & $5 \%$ & $4,5 \%$ & - & Jafari et al, 2006 \\
\hline Tomato pulp & $19,17 \%$ & $36,16 \%$ & $10,3 \%$ & - & $1,1 \%$ & $0,21 \%$ & - & Jouzi et al, 2015 \\
\hline Tomat waste & $17,56 \%$ & $49,53 \%$ & $9,59 \%$ & - & - & . & - & Alvarado et al, 2001 \\
\hline Tomat waste & $21,22 \%$ & $43,15 \%$ & $14,42 \%$ & - & $0,51 \%$ & $0,61 \%$ & $350 \mathrm{ppm}$ & $\begin{array}{l}\text { Habanabashaka, } \\
\text { et al, } 2014\end{array}$ \\
\hline $\begin{array}{l}\text { Tomato } \\
\text { pomace } 2\end{array}$ & $19,68 \%$ & $29,79 \%$ & $8,1 \%$ & $\begin{array}{l}1730 \\
\mathrm{kkal} / \mathrm{kg}\end{array}$ & $0,42 \%$ & $0,31 \%$ & - & $\begin{array}{l}\text { Safamehr, et al, } \\
2011\end{array}$ \\
\hline $\begin{array}{l}\text { Limbah } \\
\text { tomat } \\
\text { kaleng }\end{array}$ & $18,80 \%$ & $31,00 \%$ & $12,2 \%$ & $\begin{array}{l}1760 \\
\mathrm{kkal} / \mathrm{kg}\end{array}$ & $0,41 \%$ & $0,54 \%$ & - & Squires, et al, 1992 \\
\hline
\end{tabular}

Keterangan: tomat utuh: limbah tomat belum diolah yang masih utuh dan tidak termanfaatkan; tomat waste $^{1}$ : limbah tomat dari industri dan hotel(daging dan kulit);tomato pomace: limbah tomat kaleng yang terdiri dari daging, kulit, dan pulp; tomat waste ${ }^{2}$ : by-product dari pemrosesan tomat yang terdiri dari kulit, biji, bibit, cairan, dan tomat sortiran yang berwarna hijau; tomato pulp: limbah tomat dari industri jus tomat.

Salah satu keunggulan buah tomat adanya kandungan likopen yang tinggi. Kandungan likopen dari total karoten dalam tomat sebanyak $60-64 \%$ (Clinton,
1998) atau 83\% (Shi, et al., 1999). Perbandingan kandungan karoten pada tomat dapat dilihat pada Gambar 2.

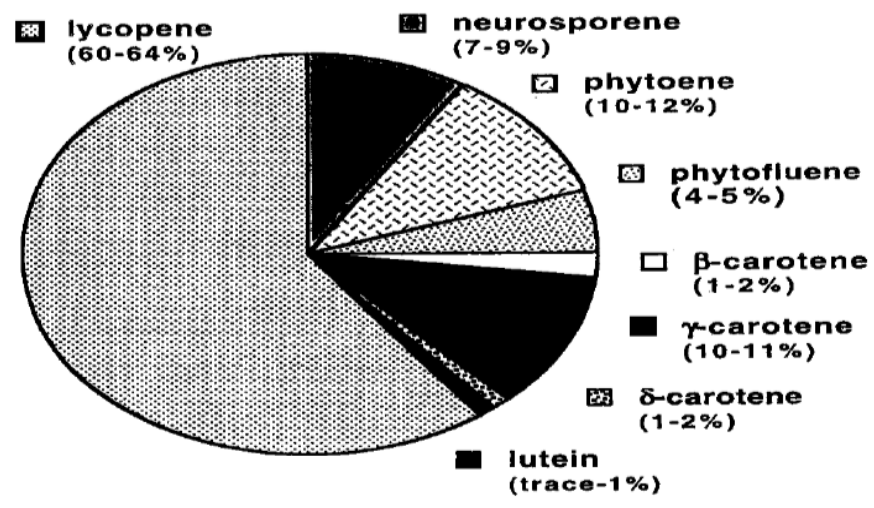

Gambar 2. Kandungan karoten pada tomat (Sumber : Clinton, 1998). 
Fungsi likopen sama seperti karoteniod pada tumbuhan yaitu membantu proses fisiologi tumbuhan, pertumbuhan tanaman, perkembangan dan stimulus terhadap lingkungan (Liu et al., 2015). Shi et al. (1999) menambahkan likopen mampu menangkap singlet oksigen dua kali lipat dari $\beta$ karoten atau 10 kali lipat dari a tokoferol. Hal itu disebabkan struktur likopen yang terdiri dari rantai poliena tetraterpen hidrokarbon dengan 11 ikatan rangkap terkonjugasi (Gambar 3).

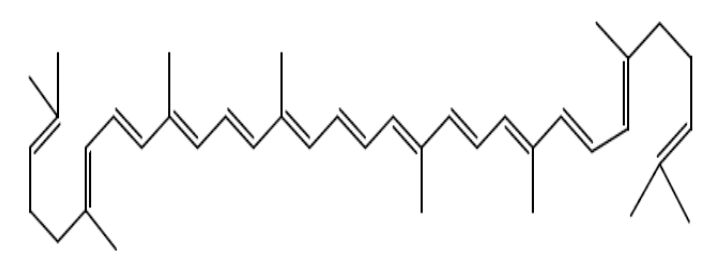

Gambar 3. Struktur Likopen (Sumber: Chauhan, et al., 2011)

\section{KEISTIMEWAAN LIKOPEN PADA TOMAT.}

Likopen merupakan salah satu senyawa karoten pada tumbuhan. Salah satu fungsi likopen adalah membantu fotosintesis, terutama membantu penyerapan cahaya dan melindungi agenagen yang menghambat fotosintesis (Demmig-Adams et al., 1996). Likopen telah banyak dilaporkan memiliki manfaat bagi manusia seperti untuk anti kanker, antioksidan, pencegah penyakit kardiovaskuler, osteoporosis dan penyakit tulang lainnya, hipertensi, neuro degeneratif, meningkatkan fertilitas (Rao, et al., 2006 dan Ajmera, 2006) dan mempengaruhi metabolisme kolesterol (Palozza, et al., 2012).

Berbagai hasil penelitian likopen mempunyai banyak fungsi biologis dalam tubuh hewan ataupun manusia. Likopen berfungsi sebagai zat antioksidan yang tinggi, untuk mencegah reaksi oksidatif di dalam sel (Young and Lowe, 2001; Stahl and Sies, 2003; Tapiero et al., 2004). Likopen dapat memperbaiki Gap-Junction
Comunication pada sel saraf yaitu mempercepat sampainya impuls syaraf dari sel saraf satu ke sel syaraf lainnya (Aust et al., 2003; Tapiero et al., 2004; Omoni and Aluko, 2005). Likopen dapat mencegah berbagai penyakit kronis seperti kanker prostat (Giovannuci et al., 1999), kanker kolon (Arab, et al., 2002), diabetes tipe 2 (Wang, et al., 2006), penyempitan pembuluh darah (Sesso, et al., 2003) serta dapat memelihara kesehatan kulit (Stalh, et al., 2001) dan meningkatkan fertilitas (Gupta and Kumar, 2002). Likopen juga dikenal mempunyai kemampuan menurunkan kolesterol (Fuhramn et al., 1997; Rao, et al.,2006; Palozza, et al., 2012).

Penggunaan likopen untuk ternak telah dilaporkan beberapa peneliti. Sun et al. (2014) melaporkan pemberian likopen pada ransum induk ayam petelur (parent stok) dapat meningkatkan fertilitas dan kapasitas antioksidan pada serum darahnya. Hsu, et al. (2015) melakukan penelitian dengan memberikan likopen yang di produksi oleh bakteri $E$. Coli nyata menurunkan total trigliserida dalam kuning telur burung puyuh.

Mekanisme penghambatan sintesis kolesterol oleh likopen adalah dengan menghambat aktivitas enzim HMG-CoA (3-hydroxy-3-methylglutaryl-coenzyme A) (Fuhramn et al., 1997; Palozza, et al., 2012). Lebih lanjut lagi Palozza, et al. (2012) penghambatan kolesterol intraseluler oleh likopen dalam sintesis kolesterol melalui penghambatan aktivitas HMG-CoA reduktase, meningkatkan aktifitas reseptor LDL dan menghambat aktivitas Kolesterol Acil tranferase (ACAT). Aktifitas HMG-CoA reduktase ini dapat menghambat sintesis kolesterol karena menghambat terbentuknya mevalonat sebagai dasar pembentukan kolesterol. Meningkatnya aktifitas reseptor LDL akan menyebabkan meningkatnya perombakan LDL yang menyebabkan turunnya jumlah LDL dalam darah. Penghambatan aktifitas ACAT akan membuat menurunnya 
penyimpanan kolesterol dalam bentuk kolesterol ester dalam jaringan. Mekanisme penghambatan likopen dalam penurun kolesterol dapat di rangkum pada Gambar 4.

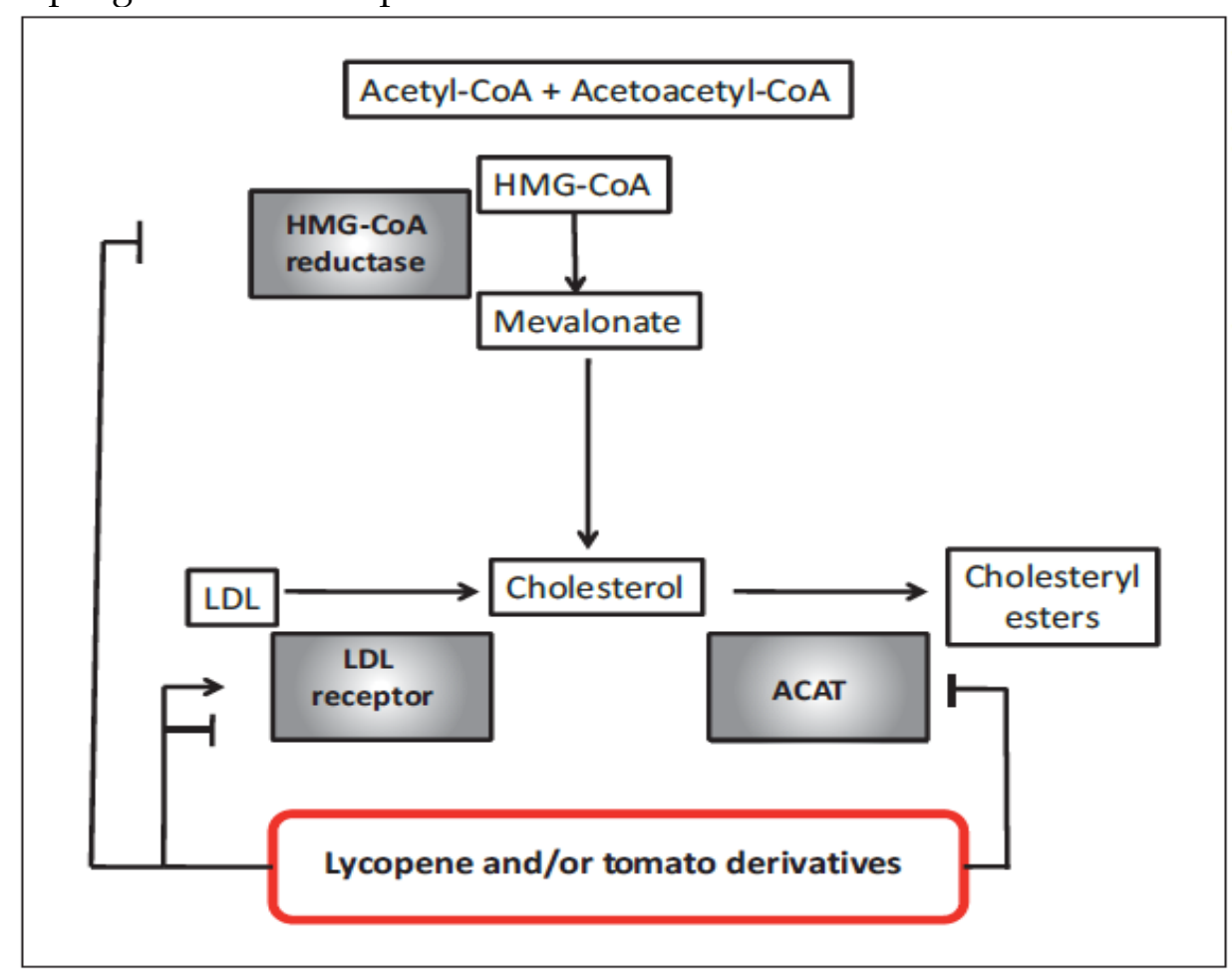

Gambar 4. Mekanisme penurunan secara intraseluler kolesterol oleh likopen (Sumber: Palozza, et al., 2012).

\section{PENGGUNAAN LIMBAH TOMAT SEBAGAI PAKAN TERNAK UNGGAS.}

Kandungan nutrisi yang sangat baik dan tingginya kandungan likopen dalam tomat dan produk sampingnya maka telah banyak di temukan penggunaan berbagai jenis limbah tomat di berbagai negara untuk di jadikan pakan. Berbagai jenis limbah dari industri tomat hingga penggunaan tomat utuh telah banyak dilakukan. Berikut perkembangan penelitian limbah tomat untuk ternak unggas dirangkum dalam Tabel 3.

Tabel 3. Penelitian penggunaan limbah tomat sebagai pakan ternak unggas

\begin{tabular}{|c|c|c|c|c|}
\hline $\begin{array}{c}\text { Sumber } \\
\text { literatur/ } \\
\text { negara }\end{array}$ & $\begin{array}{l}\text { Jenis } \\
\text { Limbah } \\
\text { Tomat }\end{array}$ & $\begin{array}{c}\text { Ternak } \\
\text { Percobaan }\end{array}$ & Dosis & Hasil \\
\hline $\begin{array}{l}\text { Squires et. al } \\
\text { (1992) / } \\
\text { Inggris }\end{array}$ & $\begin{array}{l}\text { Limbah } \\
\text { tomat } \\
\text { kaleng }\end{array}$ & Broiler & $20 \%$ & $\begin{array}{l}\text { Pemberian limbat tomat kaleng dengan } \\
\text { perlakuan autoclave, asam dan alkali dapat } \\
\text { menurunkan Feed Consumtion Rate (FCR) } \\
\text { pada ayam broiler dibandingkan dengan } \\
\text { tidak diberikan perlakuan }\end{array}$ \\
\hline $\begin{array}{l}\text { Dotas, et. al } \\
\text { (1999) / } \\
\text { Florida AS }\end{array}$ & Pulp & Layer & $12 \%$ & $\begin{array}{l}\text { Perlakuan tidak mempengaruhi terhadap } \\
\text { produksi telur, efisiensi ransum, konsumsi } \\
\text { ransum, berat telur dan ketebalan kerabang, } \\
\text { tetapi meningkatkan warna kuning telur. }\end{array}$ \\
\hline
\end{tabular}




\begin{tabular}{|c|c|c|c|c|}
\hline $\begin{array}{l}\text { Persia,et. al., } \\
\text { (2003) / } \\
\text { Amerika } \\
\text { Serikat }\end{array}$ & Biji tomat & Broiler & $15 \%$ & $\begin{array}{l}\text { Dari hasil percobaannya didapatkan lebih } \\
15 \% \text { dapat menggantikan bubuk jagung dan } \\
\text { kedelai tanpa berpengaruh terhadap } \\
\text { pertambahan bobot badan, konsumsi, FCR } \\
\text { pada broiler. Limbah biji tomat ini tidak } \\
\text { mempengaruhi perubahan warna pada } \\
\text { shank broiler. }\end{array}$ \\
\hline
\end{tabular}

King, et. al., $\quad$ Pomace $\quad$ Broiler $\quad 5 \% \quad$ Pemberian sebanyak 5\% tanpa menurunkan (2004) /

California AS

Nikolakakis, Pulp $\quad$ Puyuh $10 \%$

et. al., (2004) /

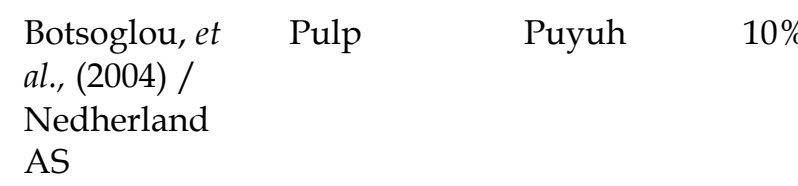

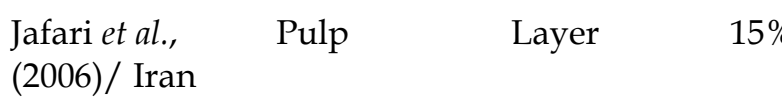

Nobakht and Pomace $\quad$ Layer $\quad 10 \%$

Safamehr

(2007)/ Iran

B. Mansoori,
et al., (2008) /

Sahin. et al., Bubuk $\quad$ Puyuh $5 \%$

(2008) / Turki tomat utuh produksinya.

Hasil yang didapatkan adalah tidak mempengaruhi terhadap performa (BBT, konsumsi ransum, dan FCR); tidak mempengaruhi bobot karkas, persentase karkas, panjang dan berat saluran cerna; tidak mempengaruhi kadar air, protein kasar dan abu karkas tetapi menurunkan kandungan lemak karkas pada perlakuan yang diberikan DTP; menurunkan warna karkas yang diberi DTP; dan tidak berpengaruh pada kandungan asam lemak karkas.

Hasil yang didapatkan adalah dengan pemberian DTP pada level 10\% menghasilkan total asam lemak tak jenuh pada daging paling tinggi dari semua perlakuan, dan total MDA dalam daging tidak berbeda nyata setelah dilakukan penyimpanan

Pemberian bubuk tomat pulp pada ayam petelur pada umur 27-38 minggu sampai $100 \mathrm{~kg} /$ ton dapat meningkatkan produksi telur, dan masa telur, sebanyak 2,7 dan 4,1\% tetapi pemberian $150 \mathrm{~kg} /$ ton dapat menurunkan produksi produksi dan masa telur sebanyak 3,6 dan 3,0\%.

Pemberian bubuk tomat (Dry Tomato Pomace) pada ayam petelur pada umur 65-78 minggu sebanyak $10 \%$ dapat meningkatkan produksi telur tetapi tidak berpengaruh pada kadar kolesterol pada serum dan kuning telurnya.

Pemberian DTP (Dry Tomato Pomace) sampai $100 \mathrm{~g} / \mathrm{kg}$ sebagai pengganti gandum tidak berpengaruh terhadap performa dan kualitas telur tapi berkontribusi terhadap warna telur.

Didapatkan hasil bahwa supplementasi bubuk tomat dapat meningkatkan konsumsi, pertambahan bobot badan dan konversi ransum di bawah tekanan stres panas, tetapi masih di bawah pada perlakuan 


\begin{tabular}{|c|c|c|c|c|}
\hline & & & & $\begin{array}{l}\text { termoneutral. Stres panas diindikasikan } \\
\text { dengan nyata terjadinya peningkatan } \\
\text { malondialdehide dan menurunnya } \\
\text { konsentrasi vitamin dalam serum, hati dan } \\
\text { otot. Pada ternak yang diberi suplementasi } \\
\text { bubuk tomat baik yang diberi heat stress } \\
\text { ataupun tidak menunjukan adanya } \\
\text { peningkatan konsentrasi likopen, vitamin C, } \\
\text { E, dan A dalam serum dan menurunnya } \\
\text { malondialdehide dalam serum. }\end{array}$ \\
\hline $\begin{array}{l}\text { Rahmatnejad } \\
\text { et al.,(2009)/ } \\
\text { Iran }\end{array}$ & Pomace & Broiler & $24 \%$ & $\begin{array}{l}\text { Pemberian DTP (Dry Tomato Pomace) hingga } \\
\text { level } 24 \% \text { dapat menurunkan kolesterol, } \\
\text { LDL dan VLDL serta meningkatkan } \\
\text { trigliserida dan HDL dalam serum darah } \\
\text { broiler. }\end{array}$ \\
\hline $\begin{array}{l}\text { Calislar and } \\
\text { Uygur, } \\
(2010) / \text { Turki }\end{array}$ & Pulp & Layer & $20 \%$ & $\begin{array}{l}\text { Penggunaan bubuk tomat kering (pulp) } \\
\text { sebesar } 20 \% \text { dapat digunakan untuk pakan } \\
\text { ayam petelur dan mempunyai effek yang } \\
\text { signifikan terhadap kualitas internal dan } \\
\text { eksternal telur. }\end{array}$ \\
\hline $\begin{array}{l}\text { Lira, et } \\
\text { al.,(2010)/ } \\
\text { Brazil }\end{array}$ & $\begin{array}{l}\text { Limbah } \\
\text { tomat } \\
\text { industri }\end{array}$ & Broiler & $20 \%$ & $\begin{array}{l}\text { Hasil yang didapat adalah selama periode } \\
1-28 \text { hari menurunkan BBT dan konversi } \\
\text { ransum, dan periode } 29--42 \text { hari pemberian } \\
\text { ningga } 20 \% \text { tidak mempengaruhi bobot } \\
\text { badan dan konversi ransumnya. }\end{array}$ \\
\hline $\begin{array}{l}\text { Melkamu, } \\
\text { et al.,(2011)/ } \\
\text { Ethiopia }\end{array}$ & Pomace & $\begin{array}{l}\text { Layer } \\
\text { strain } \\
\text { Rhode } \\
\text { Island Red }\end{array}$ & $15 \%$ & $\begin{array}{l}\text { Hasil yang didapatkan adalah pemberian } \\
\text { DPT yang disubtitusi dalam ransum } \\
\text { komersial tidak mempengaruhi performa } \\
\text { dan dapat meningkatkan efisiensi secara } \\
\text { ekonomi. }\end{array}$ \\
\hline $\begin{array}{l}\text { Safamehr, } \\
\text { et al.,(2011)/ } \\
\text { Iran }\end{array}$ & $\begin{array}{l}\text { Pomace } \\
\text { dengan } \\
\text { multi enzim }\end{array}$ & Layer & $12 \%$ & $\begin{array}{l}\text { Pemberian bubuk tomat (dry tomato } \\
\text { pomace) dengan dan tanpa kombinasi multi } \\
\text { enzim yang diberikan hingga level } 12 \% \\
\text { dapat meningkatkan performa (bobot telur, } \\
\text { massa telur, produksi telur, konsumsi } \\
\text { ransum dan efisiensi), tidak mempengaruhi } \\
\text { kualitas telur dan kolesterol dalam serum. } \\
\text { semuanya tidak berbeda pada perlakuan } \\
\text { yang diberi enzim dan tidak diberi enzim } \\
\text { pada ayam petelur. }\end{array}$ \\
\hline $\begin{array}{l}\text { Salajegheh, } \\
\text { et al.,(2012)/ } \\
\text { Iran }\end{array}$ & Pomace & Layer & $19 \%$ & $\begin{array}{l}\text { Hasil yang mereka dapat adalah perlakuan } \\
\text { yang mereka lakukan tidak memberikan } \\
\text { pengaruh yang signifikan terhadap bobot } \\
\text { badan, konsumsi, produksi telur, FCR, berat } \\
\text { telur, masa telur, bobot kulit telur, ketebalan } \\
\text { kulit telur dan HU telur. Warna kuning telur } \\
\text { meningkat seiring dengan dosis DTP yang di } \\
\text { berikan. Total protein, trigliserida, kolesterol, } \\
\text { albumin, glukosa, LDL dan HDL tidak } \\
\text { berpengaruh dengan penambahan DTP. }\end{array}$ \\
\hline
\end{tabular}




\begin{tabular}{|c|c|c|c|c|}
\hline $\begin{array}{l}\text { Vasupen, } \\
\text { et al.,(2012)/ } \\
\text { Thailand }\end{array}$ & $\begin{array}{l}\text { Pomace } \\
\text { dengan } \\
\text { enzim } \\
\text { fiboilitik }\end{array}$ & Layer & $10 \%$ & $\begin{array}{l}\text { Hasilnya adalah perlakuan yang diberikan } \\
\text { tidak mempengaruhi performa, produksi } \\
\text { telur, bobot telur dan kualitasnya. } \\
\text { Pemberian enzim dapat meningkatkan } \\
\text { warna kuning telur dibandingkan yang } \\
\text { tidak diberi enzim. }\end{array}$ \\
\hline $\begin{array}{l}\text { Selcuki, } \\
\text { et al.,(2013)/ } \\
\text { Turki }\end{array}$ & Pulp & $\begin{array}{l}\text { Parent } \\
\text { stock } \\
\text { broiler }\end{array}$ & $5 \%$ & $\begin{array}{l}\text { Hasil yang didapatkan adalah perlakuan } \\
\text { dapat menurunkkan maloneldehide (MDA); } \\
\text { meningkatkan kosentrasi semen; } \\
\text { menurunkan persentase total abnormalitas } \\
\text { sperma; serta meningkatkan motility } \\
\text { sperma. }\end{array}$ \\
\hline
\end{tabular}

\begin{tabular}{|c|c|c|}
\hline $\begin{array}{l}\text { Yitbarek, } \\
\text { et al.,(2013)/ }\end{array}$ & Pomace & $\begin{array}{l}\text { Layer } \\
\text { strain RIR }\end{array}$ \\
\hline
\end{tabular}

Jalalinasab. Pomace $\quad$ Layer $\quad 16 \%$

et al., (2014)/

Iran

\begin{tabular}{|c|c|c|}
\hline $\begin{array}{l}\text { Habanabasha } \\
\text { ka et al., } \\
\text { (2014)/ Iran }\end{array}$ & $\begin{array}{l}\text { Limbah } \\
\text { (kulit, biji, } \\
\text { pulp) }\end{array}$ & Layer \\
\hline
\end{tabular}

Leke, J. R.,
et al.,(2015)

Tomat utuh Layer

$8 \%$

Hasil yang diperolehnya adalah pemberian DTP meningkatkan konsumsi bahan kering dibandingkan kontrol; tidak mempengaruhi bobot badan dan FCR; tetapi dapat mengurangi biaya pakan sehingga meningkatkan efisiensi secara ekonomi.

Pemberian TWM (Tomato Waste Meal) setelah dilakukan pemprosesan dengan perendaman dalam larutan asam dan basa hingga level $16 \%$ tidak berpengaruh terhadap performa, kualias telur, kolesterol, albumin, total protein dan glukosa dalam serum darah pada semua perlakuan. Tetapi pada perlakuan yang direndam dalam basa terjadi peningkatan heteropil dan penurunan limposit

Pemberian TWM (Tomato Waste Meal) hingga $6 \%$ dalam ransum dapat digunakan tanpa berpengaruh terhadap produksi telur dan kualitasnya. Pada level ini juga dapat meningkatkan warna kuning telur, menurunkan kolesterol kuning telur dan meningkatkan konsentrasi likopen dalam kuning telur. Pemberian pada level 9\% menurunkan produksi telur dan meningkatkan FCR.

/Indonesia

Timbuleng,

et al., (2015)/

Tomat utuh Layer

$8 \%$

Indonesia

Jouzi, et al.,

Pulp

Puyuh

$8 \%$

(2015)/ Iran

Bubuk tomat (Tomato Waste Meal) dapat digunakan sebagai alternatif pakan pada ayam petelur yang disubtitusi dalam ransum sampai level $8 \%$ tidak berpengaruh negatif pada kualitas telur.

Penambahan bubuk tomat dalam pakan sebanyak $8 \%$ memberikan respon yang baik terhadap index kuning telur, haugh unit, dan warna kuning telur ayam petelur.

Hasil yang diperoleh adalah pemberian hingga $4 \%$ tidak berpengaruh terhadap BBT dan konsumsi ransum, tetapi pemberian 6-8\% menurunkan BBT dan konsumsi ransum, dan tidak mempengaruhi parameter 
(2016)

darah (total trigliserida, kolesterol, protein, $\mathrm{Cu}, \mathrm{Zn}$ dan $\mathrm{Fe}$ )

Mahata et al., Tomat utuh Broiler 7\%

Pemberian bubuk tomat (Lycopercison Esculentum) afkir sebanyak $7 \%$ dengan kombinasi $75 \%$ TT dan 25\% TTR dalam ransum dapat mempertahankan konsumsi ransum,dan pertambahan berat badan ayam broiler.

Pemanfaatan limbah hasil pengolahan tomat seperti limbah pembuatan saus, jus dan pasta telah banyak dilakukan oleh peneliti. Tanpa pengolahan sebagai pakan pada ayam petelur belum banyak menunjukan aktifitasnya sebagai penurun kolesterol yang diberikan hingga 15\% (Jafari, et al., 2006), 10\% (Nobakhat and Safamehr, 2007), 12\% (Safamehr, et al., 2011), 9\% (Habanabashaka, et al., 2014), 8\% (Leke, et al., 2015) bahkan menurunkan produksi telur (Jafari, et al., 2006; Habanabashaka, et al., 2014), hal ini diduga karena ketersediaan likopen pada tomat rendah yang disebabkan likopen pada tomat masih terjebak di dalam matriks jaringan kulit tomat dan struktur likopen dalam bentuk trans yang sulit diserap (Boileau, et al., 1999; Shi and Maguer, 2000; Svelander, 2011; Knockaert, et al., 2012).

Jalalinasab, et al. (2014) melakukan pengolahan limbah tomat dari pembuatan saus tomat menggunakan larutan asam $(\mathrm{HCl})$ dan basa $(\mathrm{NaOH})$ pada ayam petelur diberikan hingga $16 \%$ pada masing-masing perlakuan dan hasilnya tidak mempengaruhi performa ayam petelur, kualitas telur dan kualitas darahnya. Dilaporkan juga bahwa terjadi penurunan persentase heterofil dan meningkatkan limfosit, yang menandakan peningkatan sistem imunitas tubuh ternak. Hal ini juga kemungkinan berhubungan dengan meningkatnya penyerapan likopen pada tubuh ternak sehingga fungsi likopen sebagai agen pemacu kekebalan tubuh bekerja dengan baik.

\section{METODE PENGOLAHAN TOMAT UNTUK MENINGKATKAN KUALITAS LIKOPEN.}

Bioavailabilitas didefinisikan sebagai fraksi nutrisi yang dapat dicerna dan tersedia untuk tubuh melalui penyerapan untuk pemanfaatan dalam fungsi fisiologis normal dan proses metabolisme (Macrae et al, 1993; Jackson, 1997). Penyerapan likopen dari bahan pakan dapat ditingkatkan oleh beberapa faktor yaitu memutuskan matrik jaringan yang membawa likopen, memberikan panas selama pemprosesan, hadirnya lipid, atau komponen karoten lain yang larut dengan lemak (Clydesdale, 1993). Absorpsi likopen sama dengan absorbsi lipid. Likopen dan karotenoid yang lain ditransportasi dari mukosa usus melalui sistem limpatik (Palozza, et al., 2012).

Borel (2003) menyatakan zat makanan mikronutrien yang larut dalam lemak antaranya vitamin yang larut dalam lemak (A, E, D dan K) dan fitokimia, karotenoid dan pitosterol. Namun, pencernaan tergantung pada masing-masing jenis bahan tersebut. Colle, et al. (2010) menambahkan nilai gizi bahan pangan tidak hanya ditentukan oleh jumlah kandungan, tetapi juga oleh bioaccessibility nutrisi. Hal ini di buktikan oleh penelitian Dewanto et al. (2002) bahwa pengolahan panas meningkatkan aktivitas total antioksidan dan ketersediaan likopen dalam tomat dan tidak menghasilkan perubahan yang signifikan dalam total fenolat dan jumlah konten flavonoid, meskipun hilangnya vitamin $\mathrm{C}$ diamati. Tomat mentah memiliki 0,76 IMOL vitamin C/g tomat. Setelah 2, 15, dan 30 
menit dari pemanasan pada $88^{\circ} \mathrm{C}$, kandungan vitamin $\mathrm{C}$ secara signifikan turun ke 0,$68 ; 0,64$; dan 0,54 IMOL vitamin $\mathrm{C} / \mathrm{g}$ tomat, masing-masing $(\mathrm{p}<0,01)$. Tomat mentah memiliki $2.01 \mathrm{mg}$ trans-likopen /g tomat. Setelah 2, 15, dan 30 menit dari pemanasan pada $88^{\circ} \mathrm{C}$, trans-lycopenetelah meningkat menjadi 3,11, 5,45, dan 5,32 mg trans-likopen/g tomat $(\mathrm{p}<0,01)$.

Boileau et al. (1999) melaporkan cis-likopen lebih mudah dicerna daripada trans-likopen. Likopen dapat mengalami isomerisasi dari trans ke cis karena cahaya, energi panas dan reaksi kimia (Shi et al., 1999; Tapiero, et al., 2004; Goula, et al., 2006). Likopen stabil terhadap panas selama pemprosesan dan penyimpanan (Clinton, et al., 1998).

Metode-metode pengolahan tomat
telah banyak dilakukan untuk meningkatkan kandungan likopen. Thompson et al. (2000) melaporkan pengolahan tomat melalui perebusan tomat pada air mendidih suhu $100^{\circ} \mathrm{C}$ selama 8 menit dapat meningkatkan kandungan likopen terbaik. Sahlin, et al. (2004) melakukan pengolahan melalui penggorengan selama 4 menit pada minyak zaitun, pembakaran selama 18 menit dan perendaman pada asam cuka selama 20 menit suhu $20^{\circ} \mathrm{C}$. Papaioannou et al. (2012) juga melakukan usaha peningkatan likopen dengan pemberian enzim Citrozym ${ }^{\circledR}$. Stahl and Sies (1992) melaporkan perebusan dengan penambahan $1 \%$ minyak jagung pada jus tomat dapat meningkatkan kadar likopen pada serum darah manusia.

Penelitian Fielding et al (2005) memberikan $470 \mathrm{~g}$ tomat yang dimasak dengan minyak zaitun sebanyak $25 \mathrm{ml}$ yang diberikan selama 5 hari pada objek. Hasil yang didapat adalah secara nyata meningkatkan $82 \%$ trans likopen dan $40 \%$ cis likopen dalam serum darah. Sehingga pada penelitian ini memperlihatkan bahwa dengan penambahan minyak membantu penyerapan likopen karena membantu ekstrasi likopen dalam fase lipofilik. Hengan hadirnya lipid/minyak ini membantu menstimulus kelenjar pankreas untuk mensekresikan asam empedu untuk membentuk misel, misel ini akan terbentuk apabila lipid tersedia secara cukup dalam saluran cerna. Selain itu dengan pemanasan ini menyebabkan putusnya sel jaringan kulit untuk melepaskan likopen, sehingga likopen lebih tersedia. Mahata, et al. (2016) melakukan pengolahan tomat dengan perebusan selama 8 menit dapat meningkatkan kandungan likopen dan menurunkan kolesterol pada karkas broiler.

Sehingga dapat disimpulkan bahwa untuk meningkatkan ketersediaan likopen maka hal yang dibutuhkan adalah bagaimana cara melepaskan likopen dari matrik jaringan tomat. Lalu kemudian meningkatkan penyerapan dengan memperbanyak kandungan cis likopen serta memberikan bahan yang dapat meningkatkan penyerapan seperti lipid.

\section{KESIMPULAN}

Tomat merupakan produk pertanian yang melimpah di Indonesia. Tomat juga belum banyak dimanfaatkan terutama pada buah tomat yang afkir. Buah tomat afkir memiliki kandungan nutrisi yang cukup baik untuk dijadikan sumber bahan pakan dan mengandung likopen tinggi. Likopen merupakan senyawa karotenoid yang dapat digunakan untuk meningkatkan kualitas produk ternak dan sebagai sumber antioksidan yang tinggi. Likopen pada tomat masih sulit dicerna dan diserap. Oleh karenanya pengolahan seperti pemberian panas atau pemasakan serta penambahan lipid sangat baik dilakukan sebelum diberikan kepada ternak unggas. 


\section{DAFTAR PUSTAKA}

Agarwal, S. and Rao, A. V. 1998. Tomato lycopene and low density lipoprotein oxidation: a human dietary intervention study. Lipids, 33, 981-984.

Agustinus, M. 2015. Produksi Tomat RI surplus 400 ribu ton tiap Tahun. Dipiblikasikan Senin 17 Aug 2015.https:/ / finance.detik.com/ekonomibisnis/2993802/produksi-tomat-risurplus-400-ribu-ton-tiap-tahun.

Ajmera. S. 2006. The Effects of Different Cooking Times and Temperatures on Tomato Sauce Lycopene Content. Thesis. Bowling Green State University.

Alvarado A., Pacheco-Delahaye E. and Hevia P. (2001). Value of a tomato by-product as a source of dietary fiber in rat. Plant Foods Hum. Nutr. 56, 335-348.

Arab L, Steck-Scott S, and Fleishauer AT. 2002. Lycopene and the lung. Exp Biol Med 227: 894-99.

Aust O, N. Ale-Agha, L. Zhang, H. Wollersen, H. Sies, and W. Stahl. 2003. Lycopene oxidation product enhances gap junctional communication. Food and Chemical

B. Mansoori, Modirsanei, M. and Kiaei, M. M. 2008. Influence of Dried Tomato Pomace as an Alternative to Wheat Bran in Maize or Wheat Based Diets, on thePerformance of Laying Hens and Traits of Produced Eggs. Iranian Journal of Veterinary Research, Shiraz University, 9(4):25.

Boileau, A. C., Merchen, N. R., Wasson, K., Atkinson, C. A., and Erdman, J. W. 1999. Cis-lycopene is more bioavailable than translycopene in vitro and in vivo in lymph-cannulated ferrests. J. Nut., 129, 1176-1181.

Borel, Patrick. 2003. Factors Affecting Intestinal Absorption of Highly Lipophilic Food Microconstituents (Fat-Soluble Vitamins, Carotenoids and Phytosterols). Clin Chem Lab Med 2003; 41(8):979-994.
Botsoglou. N, G. Papageorgiou, I. Nikolakakis, P. F. Paneri, I. Giannenas, V. Dotas, and E. Sinapis. 2004. Effect of Dietary Dried Tomato Pulp on Oxidative Stability of Japanese Quail Meat. J. Agric. Food Chem. 2004, 52, 2982-2988.

Calislar. S and G. Uygur. 2010. Effect of Dry Tomato Pulp on Yolk Pigmentation and Some Egg Yield Charectiristics of Laying Hens. Journal of Animal and Veterinery Advance 9 (1): 96-89.

Chauhan. K, S. Sharma, N. Agarwal, and B. Chauhan. 2011. Lycopene of Tomato Fame: Its Role in Health and Disease. International Journal of Pharmaceutical Sciences Review and Research. 10(1):Article-018.

Clinton. S. K. 1998. Lycopene: Chemistry, Biology, and Implications for Human Health and Disease. J. Nutrition Reviews, 56(2): 35-51.

Clydesdale, F. M. 1993. Color as a factor in food choice. Crit. Rev. Food Sci. Nutr., 33(1), 83-101.

Colle. I., L. Lemmens, S.V. Buggenhout, A.V. Loey, and M. Hendrickx. 2010. Effect of hermal Processing on the Degradation, Isomerization, and Bioaccessibility of Lycopene in Tomato Pulp. Journal of Food Science Vol. 75, Nr. 9, 2010.doi: 10.1111/j.1750-3841.2010.01862.x.

Demmig-Adams, B., W.W. Adams, D. H. Barker, B. A. Logan, D. R. Bowling, A. S. Verhoeven. 1996. Using Chlorophyll Fluorescence to Assess the Fraction ff Absorbed Light Allocated to Thermal Dissipation of Excess Excitation. An International Journal for Plant Biology.Volume 98, Issue 2 October1996 Pages 253-264. DOI: $10.1034 /$ j.13993054.1996.980206.x

Dewanto. V, X. Wu, K.K. Adom, and R. H. Liu. 2002. Thermal Processing Enhancesthe utritional Value of Tomatoes by Increasing Total Antioxidant Activity. J.Agric. Food Chem. 2002, 50, 3010-3014. DOI: 10.1021/jf0115589 
Dotas. D, S. Zamanidis, and J. Balios. 1999. Effect of dried tomato pulp on the performance and egg traits of laying hens. British Poultry Science (1999) 40: 695-697.

Fielding. J.M, K.G. Rowley, P. Cooper, and K. O'Dea. 2005. Increases in Plasma Lycopene Concentration After Consumption of Tomatoes Cooked With Olive Oil. Asia Pac J Clin Nutr 200514 (2):131-136.

Fuhramn, B., Elis, A., and Aviram, M. 1997. Hypocholesterolemic Effect of lycopene and b-carotene is related to suppression of cholesterol synthesis and augmentation of LDL receptor activity in macrophage. Biochem. Biophys. Res. Commun. 233, 658662.

Giovannucci, E., 1999. Tomatoes, Tomatobased Products, Lycopene, and Cancer: Review of the Epidemiologic Literature. J. Natl. Cancer Inst. 91:317-331.

Goula AM, Adamopoulos KG, Chatzitakis PC, Nikas VA. 2006. Prediction of lycopene degradation during a drying process of tomato pulp. Journal of Food Engineering 74: 37-46.

Gupta, N. P. and R. Kumar. 2002. Lycopene Therapy in Indiopathic Male Infertility-a Preliminary Report. International Urology and Nephrology 34: 369-372.

Habanabashaka. M., M. Sengabo, and I. O. Oladunjoye. Effect of Tomato Waste Meal On Lay Performance, Egg Quality, Lipid Profile and Caroten Content of Eggs in LayingHens.Iranian Journal of Applied Animal Science 4 (3): 555-559.

Hsu. W. T., C. J . Chiang., Y. P. Chao., C.H Chang., L. J. Lin., B. Yu., and T. T. Lee. 2015. Effect of Recombinant Lycopene Dietary Suplement on the Egg Quality and Blood Characteristics of Laying Quails. Journal of bioscience and Bioengineering. Vol. XX:1-5.

Jackson, M. J. 1997. The assessment of bioavailibility of micronutrients : introduction. Eur. J. Clin. Nutr.,51: S1-S2.

Jafari. M., R. Pirmohammadi, and V. Bampidis. 2006. The Use of Dried Tomato Pulp in
Diets of Laying Hens. International Journal of Poultry Science 5 (7): 618-622.

Jalalinasab. A, A. Nobakht, and S. Razzaghzadeh. 2014. The Effects of Different Levels of Tomato Pomace and Processing Methods on Production Performance and Blood Metabolites of Native Laying Hens.Iranian Journal of Applied Animal Science 4(2), 379-385.

Jannah, K. M. 2015. Tomat Berlimbah, Sayang Industri Hanya Serap Sedikit. Senin 17 Agustus 2015. Diakses 28 Mei 2016 (12.45). http://economy.okezone.com/read/2015/ 08/17/320/1197509/surplus-tomat-diindonesia-sampai-400-ribu-ton.

Jouzi. H, N. Vali, and J. Pourreza. 2015. The Effect of Tomato Pulp Powder Supplementation on Performance and Some Blood Parameters in Japanese Quail(Coturnix Japonica). ARPN Journal of Agricultural and Biological Science. 10(3).

King. A. J. and G. Zeidler. 2004. Tomato Pomace maybe a Good Source of Vitamin Ein Broiler Diets. Articel Reseacrh. California Agriculture. 58(1). http:/ / CaliforniaAgriculture.ucop.edu

Knockaert. G., S. K. Pulissery, I. Colle, S. Van Buggenhout, M. Hendrickx, And A. V. Loey. 2012. Lycopene degradation, isomerization and in vitro bioaccxcvessibility in high pressure homogenized tomato puree containing oil: Effect of additional thermal and high pressure processing. J. Food Chemistry.135. 1290-1297.

Leke. J. R., J. S. Mandey, and F.J. Nangoy. 2015. Nutrients and Cholesterol of EggsAffected by Dried Tomato Meal in Laying Hens Diet. International Journal on Advanced Science Engineering Information Technology. 5: 178-180.

Lira. R. C., C. Bôa-Viagem Rabello, M. do C. M. M. Ludke, P. V. Ferreira, G. R. Q. Lana, and S. R. V. Lana. 2010. Productive Performance of Broiler Chickens Fed Tomato Waste. R. Bras. Zootec.39(5):10741081. 
Liu L., Shao Z., Zhang M., and Wang Q. 2015. Regulation of Carotenoid Metabolism in Tomato. Review Articel. Mol. Plant.8,28-39. http://dx.doi.org/10.1016/j.molp.2014.11.0 $\underline{06}$

Macrae, R., Robinson, R. K., and Sadler, M. J. 1993. Encyclopaedia of Food Science, Food Technology and Nutrition, Academic Press, London.

Mahata, M.E, J. Malik. M. Taufik. Y. Rizal, and Ardi. 2016. Effect of Different Combinations of Unboiled and Boiled Tomato Waste in Diet on Performance, Internal Organ Development and Serum Lipid Profile of Broiler Chicken. International Journal of Poultry Science 15 (17): 283-286.

Melkamu. B, T. Yayneshet, and T. Alemayehu. 2011. Performance of Growing Rhode Island Red Chicks Fed Different Levels of Dried Tomato Pomace and a Commercial Diet. Journal of the Drylands. 4(2): 320-324.

Nikolakakis. I, D . Banakis, P. Florou -Paneri, V. Dotas, I. Giannenas, and N. Botsoglou.2004. Effect of Dried Tomato Pulp on Performance and Carcass Characteristics of Growing Quails. Arch. GeAügelk. 2004, 68 (1), 34-38, ISSN 00039098.

Nobakht. A., A. R. Safamehr. 2007. The Effect of Inclution Different Levels of Dried Tomato Pomace in Laying Hens Diets on Plasma and Egg Yolk Cholesterol Content. Journal of Animal and Veterinary Advances. 6(9):1101-1106.

Novita, I. S. 2015. Tiap tahun, produksi tomat surplus hingga 400 ribu ton. Dipublikasikan Senin, 17 Agustus 2015. Diakses 28 Mei $2016 \quad$ (12.45). https://www.merdeka.com/uang/tiaptahun-produksi-tomat-surplus-hingga-400ribu-ton.html

Olson. J. B., N. E. Ward, and E. A. Koutsos. 2008. Lycopene Incorporation into Egg Yolk and Effects on Laying Hen Immune Function. Poultry Science 87:2573-2580. doi:10.3382/ps.2008-00072
Omoni, A. O and Aluko RE. 2005. The anticarcinogenic and anti-atherogenic effects of lycopene: a review. Trends in Food Science \& Technology 16: 344-350.

Palozza. P., A. Catalano, R.E. Simone, M.C. Mele, and A. Cittadini. 2012. Effect of Lycopene and Tomato Products on Cholesterol Metabolism. Ann Nutr Metab 2012;61:126-134.DOI: 10.1159/000342077

Papaioannou, E. H.and A. J. Karabelas. 2012. Lycopene recovery from tomato peel under mild conditions assisted by enzymatic pretreatment and non-ionic surfactants. Biochimica polonica. 59(1):71-74.

Persia, M. E., C. M. Parsons, M. Schang, and J. Azcona. 2003. Nutritional Evaluation of Dried Tomato Seeds. J. Poultry Science 82:141-146.

Rahmatnejad. E., M. Bojarpour, KH. Mirzadeh, M. Chaji, and T. Mohammadabadi.2009.The Effect of Different Level of Dried Tomato Pomace on Broiler Chicken Hematological Indices. Journal of Animal and Veterinery Advance. 8 (10): 1989-1992.

Rao. A.V., M.R. Ray, and L.G. Rao. 2006. Lycopene. Advances in Food and Nutrition Research Vol 51. ISSN: 1043-4526. DOI: 10.1016/S1043-4526(06)51002-2.

Safamehr. A., H. Malek., and A. Nobakhat. 2011. Effect of Different Level of Tomato with or without Multi-Enzyme on Performance and Egg Traits of Laying Hens. Iranian Journal of Applied Animal Science 1 (1): 39-47.

Sahin. N., C. Orhan, M. Tuzcu, K. Sahin, and O. Kucuk. 2008. The Effects of Tomato Powder Supplementation on Performance and Lipid Peroxidation in Quail. Poultry Science 87: 276-283. doi:10.3382/ps.200700207.

Sahlin. E, G.P. Savage, and C.E. Lister. 2004. Investigation of the antioxidant properties of tomatoes after processing. Journal of Food Composition and Analysis.17.635647. 
Salajegheh. M.H., S. Ghazi, R. Mahdavi, and O. Mozafari. 2012. Effects of Different Levels of Dried Tomato Pomace on Performance, Egg Quality and Serum Metabolites of Laying Hens. African Journal of Biotechnology.11(87):15373-15379. DOI: 10.5897/ AJB12.1031.

Selcuki. M, Z. Selcuk, Z. Kahraman, G. Ciftci, and E. Akal. 2013. Effects of DriedTomato Pulp Used as a Feed Ingredient in Breeder Roosters' Diets on Blood and Semen Antioxidant Status and on Some Sperm Parameters. Revue Méd. Vét.164, 8-9, 435442.

Sesso, H. D., S. Liu, M. J. Gaziano, J. E. Buring. 2003. Dietary lycopene, tomato-based food products and cardiovascular disease in women. J Nutr. 133: 2336-41.

Shi, J. and M. Le Maguer. 2000. Lycopene in Tomatoes: Chemical and PhysicalProperties Affected by Food Processing. Critical Reviews in Food Science and Nutrition, 40(1):1-42.

Shi. J, Maguer ML, Kakuda Y, Liptay A, Niekamp F. 1999. Lycopene degradation and isomerization in tomato dehydration. Food Research International 32: 15-21.

Squires, M. W., E. C. Naber, and V. D. Toelle. 1992. The Effects of Heat, Water, Acid, and Alkali Treatment of Tomato Cannery Wastes on Growth, Metabolizable Energy Value, and Nitrogen Utilization of Broiler Chicks. Poultry Science 71:522-529.

Stahl, W. and H. Sies. 2003. Antioxidant activity of carotenoids, Mol Aspects Med, 24: 345-351.

Stahl. W and H. Sies. 1992. Uptake of Lycopene and Its Geometrical Isomers Is Greater from Heat-Processed than from unprocessed Tomato Juice in Humans. J. Nutr. 122: 2161-2166.

Steenis. 1997. Flora. Cetakan ke-2. Jakarta: Pradnya Paramita.
Sun. B, J. Ma, J. Zhang, L. Su, Q. Xie, and Y. Bi. 2014. Lycopene RegulatesProduction Performance, Antioxidant Capacity, and Biochemical Parameters in Breeding Hens. Czech J. Anim. Sci., 59,(10): 471-479.

Svelander. C. 2011. In vitro Bioaccessibility of Zarotenes "Influence ofmicrostructurein tomato and carrot as modified by processing".Tesis. Departmentof Chemical and Biological Engineering Chalmers University of Technology Food Science. Gothenburg. Sweden.

Tapiero, H., Townsend DM, Tew KD. 2004. The role of carotenoids in the prevention of human pathologies. Biomedicine and Pharmacotherapy 58: 100-110.

Thompson, K.A. , M.R. Marshall, C.A. Sims, C.I. Wei, S.A. Sargent, and J.W. Scott. 2000. Cultivar, Maturity, and Heat Treatment on Lycopene Content in Tomatoes. Journal of Food Science. 65(5): 791-795.

Timbuleng. V.E, J.T.Laihad, J.R. Leke, S.C. Rimbing. 2015. Pengaruh Penambahan Tepung Tomat (Solanum lycopersicum l) Terhadap Kualitas Internal Telur Ayam Ras. Jurnal Zootek 35(2):258-266.

Tugiyono. 2005. Tanaman Tomat. Agromedia Pustaka. Jakarta: 250 halaman.

Vasupen, K, S. Wongsuthavas, S. Bureenok, B. Saenmahayak, K. Ampaporn,and C. Yuangklang. 2013. Effect of Tomato Pomace and Fibrolytic Enzyme on Egg Production and EggQuality.International Journal of Biological, Biomolecular,Agricultural, Food and Biotechnological Engineering. 7(1).

Wang L., S. Liu, A. D. Pradhan, J. E. Manson, J. E. Buring, J. M, and H. D. Sesso. 2006. Plasma lycopene, other carotenoids, and the risk of type 2 diabetes in women. American Journal of Epidemiology 164 (6): 576-585.

Yitbarek. M. B. 2013. The Effect of Feeding Different Levels of Dried Tomato Pomace on the Performance of Rhode Island Red (RIR) Grower Chicks. International Journal of Livestock Production. 4(3):35-41. DOI:10.5897/IJLP12.034. 
Young, A. J., and G. M. Lowe. 2001. Antioxidant and prooxidant properties of carotenoids, Arch Biochem Biophys, 385: 20-27.
Zikria, Roydatul. 2014. Outlook Komoditi Tomat. ISSN: 1907-1507. Pusat Data dan Sistem Informasi Pertanian Sekretariat Jenderal Kementerian Pertanian; Jakarta. 